\title{
ZOOGEOGRAPHICAL DIVISION OF VIETNAM BASED ON THE ORIBATID MITE (ACARI: ORIBATIDA) FAUNA
}

\author{
Vu Quang Manh \\ Hanoi National University of Education (HNUE), vqmanh@hnue.edu.vn
}

\begin{abstract}
Soil oribatid mites (Acari: Oribatida) had been collected throughout Vietnam, including 50 sites located in 27 provinces, and from all of the 8 natural geographical regions. Up to December 2013, the oribatid fauna of Vietnam is represented by 320 species (including four subspecies) belonging to 163 genera, 64 families (including two subfamilies), and 30 superfamilies. $34.68 \%$ of the total number is probably endemic species. 155 oribatid species, representing $48.44 \%$ of the total oribatid fauna, were recorded for the first time for the fauna of Vietnam. The oribatid fauna of Vietnam occupies 3.09\% (320 vs. 10,342 species), 13.05\% (163 vs. 1,249 genera), and $38.0 \%$ (62 vs. 163 families) of the World oribatid fauna. Based on the analysis of the oribatid mite fauna, from North to South the zoogeographical division of Vietnam can be divided into six sub-divisions, as follows: (1) Region between Northwest and Northeast (North Vietnam), (2) Region of the Red River Delta (North Vietnam), (3) Region of the Red River Delta: National Park Cat Ba Island (North Vietnam), (4) Region of North Central: National Park Ben En (North Central Vietnam), (5) Region between the Uplands of the Red River Delta and the National Park Phong Nha - Ke Bang (North Vietnam and Central North Vietnam), and (6) Region of Southern (the Mekong River Delta): the National Parks of Bu Gia and of Cat Tien (South Vietnam).
\end{abstract}

Keywords: Acari: Oribatida, oribatid mite fauna, zoogeographical division, Vietnam.

\section{INTRODUCTION}

Oribatid mites (Oribatida van der Hammen, 1968) are small arachnids (0.1-0.2 to 1.0-2.0 $\mathrm{mm}$ ), and are one of the dominant animal groups involved in the metabolic cycle of matter and energy flow in the soil ecosystem. They disperse bacteria and fungi, both externally on their body surface, or by feeding, with subsequent survival of spores during passage through their alimentary tracts. A number of oribatid mites are intermediate hosts for important tapeworm parasites (Cestoda) of animals (Ghilarov \& Krivolutsky, 1975; Norton $\&$ Behan-Pelletier, 2009) [8, 20]. Therefore, research on these soil animals can contribute to discovery of new aspects of their biology and their involvement in the soil formation process.

The study on oribatid mites of Vietnam started in 1967 (Balogh \& Mahunka 1967) [3]. It continued in the 1980's, and has lead to important results (Vu Quang Manh 1980, 1985, 1990) $[13,14,15]$. However, because of the diverse fauna of the tropical soil ecosystem of Vietnam the above mentioned studies are still not enough sufficient. This work is a synthesis not only of the author's studies but also of all studies undertaken in Vietnam from 1967 until 2013, and it is based on oribatid specimens obtained throughout the country. Its aim is to characterize the zoogeographical division of Vietnam based on its oribatid mite fauna.

\section{MATERIALS AND METHODS}

\section{Study area}

During the period of 1980-2013, oribatids had been obtained throughout Vietnam, including 50 sites located in 27 provinces, and from all of the eight natural geographical regions of Vietnam ( $\mathrm{Vu} \&$ Taillard, 1994; Vietnam Ministry of Agriculture and Rural Development, 2006) [27, 31], namely Northwest, Northeast, Red River Delta, North Central Coast, South Central Coast, Central Highlands, Southeast, and Mekong River Delta (Southwest) (figure 1).

Fifty study sites studied were classified into six main habitat types (Vietnam Ministry of Agriculture and Rural Development 2006) [27]: 
(a) Natural forest, (b) Human-disturbed forest, (c) Grassland and scrub, (d) Grassland, (e) Cultivated land with perennial and annual plants, and (f) Agricultural land with annual plants. The study soils investigated were arranged in a six main groups (Vietnam National Institute for Soils and Fertilizers 2002): (i) Coastal saline-acid soil, (ii) Acid alluvial soil, (iii) Neutral alluvial soil, (iv) Ferralitic reddish brown soil, (v) Ferralitic brownish soil derived from limestone, (vi) Reddish brown soils derived from basic and intermediate magmatic rocks.

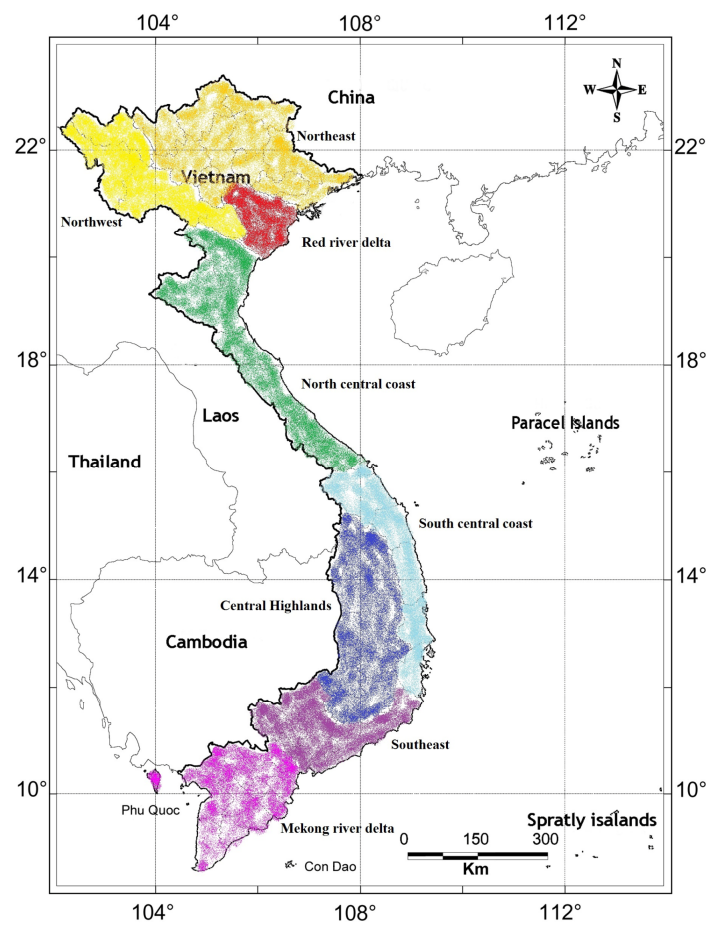

Figure 1. The Vietnamese eight natural geographical regions (Vietnam National Environment Agency, 2001: the mainland)

\section{Sampling and extraction}

Soil samples were taken according to soil deep vertical layers: (0) Forest litter, (-1) 0$10 \mathrm{~cm},(-2)>10-20 \mathrm{~cm}, \quad(-3)>20-30 \mathrm{~cm}$. Soil samples were taken by rectangular metal sampler, with $(5 \times 5) \mathrm{cm}^{2}$ surface area, $20 \mathrm{~cm}$ in depth and with both ends open. Forest litter samples were taken from the total forest litter covered an area of $(50 \times 50) \mathrm{cm}^{-2}$.

Modifications of Berlese-Tullgren funnels were used for extraction of oribatid mites from the obtained materials (Dunger \& Fiedler, 1997) [4]. An extraction lasted seven days in the laboratory at normal air condition of $25-30^{\circ} \mathrm{C}$. Extracted oribatid mites were preserved in $70^{\circ}$ ethanol, sorted and counted.

\section{Identification and data analysis}

Oribatida materials are identified mainly after Gilyarov \& Krivolutsky (1975) [8], Balogh \& Balogh $(1988,1989,2002)$ [2], Norton \& Behan-Pelletier (2009) [20], Schatz et al. (2011), and Subias (2013) [23, 24].

Species similarity indices between the oribatid communities were calculated by Jaccard index of species similarity (J).

For study of the zoogeographical division, Microsoft Office Excel 2010 and the multivariate ecological research version 6 (PRIMER 6) were used. The latter is a collection of specialized routines for analyzing species or sample abundance. Multivariate routines include grouping (Cluster), trend correlation (Best), comparisons (Relate), and calculation of diversity, dominance, and distribution.

Abbreviations used in this paper are as follows:

NP: National Park.

(I) Northwest: Xuan Son NP, (II) Northeast: Tam Dao NP, (III) Red River Delta (Upland of Che), (IV) Red River Delta, (V) Red River Delta: Cat Ba NP (Eastern Island), (VI) North Central: Ben En NP, (VII) Central North (and Central South): Phong Nha - Ke Bang NP, (VIII) Mekong River Delta (Southern): Bu Gia Map NP, and (IX) Mekong River Delta: Cat Tien NP.

Soil deep vertical layers: (0) Forest litter, (-1) 0-10 cm, (-2) $>10-20 \mathrm{~cm},(-3)>20-30 \mathrm{~cm}$.

\section{RESULTS AND DISCUSSION}

\section{Zoogeographical division of Vietnam based on its oribatid families}

Up to December 2013, the oribatid mite fauna of Vietnam is represented by 320 species (including four subspecies) belonging to 163 genera, 64 families (including two subfamilies), 
and 30 superfamilies (Balogh \& Mahunka, 1967 [3]; Vu Quang Manh, 1980, 1985, 2007, 2012, 2013 [13, 14, 16, 30, 18]; Krivolutsky, Vu \& Phan, 1997 [12]; Ermilov \& Vu, 2012 [7]; Ermilov et al. 2012 [6]). This fauna is highly diversified, with a high number of species with limited distribution, $34.68 \%$ of the total number are probably endemic species. One hundred and fifty five (155) species, representing $48.44 \%$ of the total oribatid mite fauna, were recorded for the first time for the fauna of Vietnam. The oribatid mite fauna of Vietnam occupies 3.09\% (320 vs. 10,342 species), 13.05\% (163 vs. 1,249 genera), and $38.0 \%$ (62 vs. 163 families) of the world oribatid mite fauna.

In order to characterize the zoogeographical division of Vietnam based on its oribatid mite fauna, from North to South, 50 studied sites are arranged into nine natural regions, as follows (I) Northwest with 10 sites in four provinces and cities, including two National parks, (II) Northeast with six sites in six provinces and cities, including two National parks, (III) Red River Delta (Upland of Che) with one site, (IV) Red River Delta with 16 sites in seven provinces and cities, including one National park, (V) Red River Delta with one National park Cat Ba (Eastern Island), (VI) North Central with nine sites in two provinces and cities, including one National park, (VII) Central North (and Central South) with four sites in four provinces and cities, including one National parks, (VIII) Mekong River Delta (Southern) with one National park in one province, and (IX) Mekong River Delta with two sites in two provinces, including one National park. The table 1 below presents a numbers of the oribatid families, genera and species recorded according to the studied natural geographical regions (table 1).

Table 1. Distribution of oribatid families, genera and species according to the studied natural regions

\begin{tabular}{lccccccccc}
\hline \multicolumn{1}{c}{ Natural regions } & I & II & III & IV & V & VI & VII & VIII & IX \\
\hline Naxons & 38 & 31 & 17 & 27 & 26 & 25 & 35 & 28 & 42 \\
Number of families & 66 & 52 & 29 & 45 & 38 & 42 & 61 & 45 & 81 \\
Number of genera & 119 & 81 & 32 & 62 & 49 & 58 & 83 & 60 & 120 \\
\hline
\end{tabular}

Legends: (I) Northwest: Xuan Son NP, (II) Northeast: Tam Dao NP, (III) Red River Delta (Upland of Che), (IV) Red River Delta, (V) Red River Delta: Cat Ba NP (Eastern Island), (VI) North Central: Ben En NP, (VII) Central North (and Central South): Phong Nha-Ke Bang NP, (VIII) Mekong River Delta (Southern): Bu Gia Map NP, and (IX) Mekong River Delta: Cat Tien NP.

The distribution and zoogeographical division of the oribatid mite fauna of Vietnam are analyzed according to families, genera and species grouping. The results obtained are presented in the table 2 and in the figure 2 , for families; in the table 3 and the figure 3, for genera; and in the table 4 and the figure 4 , for species.

Table 2. Jaccard similarity index of oribatid family diversity between the studied geographical regions (Legends: See the table 1)

\begin{tabular}{ccccccccc}
\hline & I & II & III & IV & V & VI & VII & VIII \\
\hline II & 76.06 & & & & & & & \\
III & 53.57 & 51.06 & & & & & & \\
IV & 68.66 & 68.97 & 51.16 & & & & & \\
V & 69.70 & 66.67 & 57.14 & 79.25 & & & & \\
VI & 67.69 & 78.57 & 53.66 & 80.77 & 74.51 & & & \\
VII & 73.97 & 75.00 & 61.22 & 76.67 & 74.58 & 79.31 & & \\
VIII & 66.67 & 50.00 & 48.89 & 57.14 & 58.18 & 59.26 & 61.29 & \\
IX & 70.73 & 65.75 & 48.28 & 60.87 & 61.76 & 65.67 & 72.00 & 70.42 \\
\hline
\end{tabular}




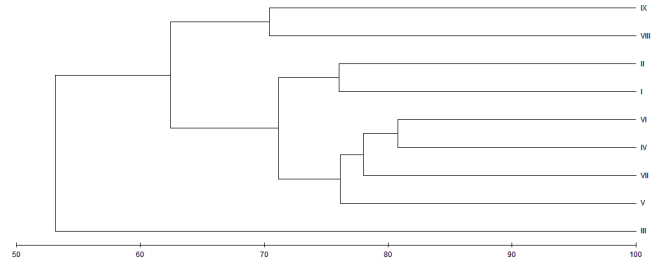

Figure 2. Cluster of similarity of oribatid family diversity between the studied geographical regions.

The distribution and zoogeographical division of the oribatid families of Vietnam are presented in table 2 and figure 2. The cluster in figure 2 shows that, from North to South of Vietnam, the Oribatid genera are grouping in four main regions, as followings:

(1) The Region between (II) Northeast and
(I) Northwest, with the similarity index of $76.06 \%$.

(2) The Region of (III) Red River Delta: Uplands, is separated from all other regions, with the similarity index of 48.28-61.22\%.

(3) The Region between (VI) North Central, (IV) Red River Delta, (VII) Central North, and (V) Red River Delta: NP Cat Ba Island, with the similarity index of 76.67-80.77\%.

(4) The Region between (VIII) Southern Mekong River Delta: NP Bu Gia Map and (IX) Southern - Mekong River Delta: NP Cat Tien, with the similarity index of $70.42 \%$.

\section{Zoogeographical division of Vietnam based on its oribatid genera}

The distribution and zoogeographical division of the oribatid genera of Vietnam are presented in the table 3 and the figure 3.

Table 3. Jaccard similarity index of oribatid genus diversity between the studied geographical regions (Legends: See the table 1)

\begin{tabular}{ccccccccc}
\hline & I & II & III & IV & V & VI & VII & VIII \\
\hline II & 63.16 & & & & & & & \\
III & 32.97 & 30.38 & & & & & & \\
IV & 64.81 & 50.00 & 38.36 & & & & & \\
V & 56.00 & 52.27 & 33.85 & 60.98 & & & & \\
VI & 61.54 & 65.22 & 37.68 & 65.12 & 58.97 & & & \\
VII & 42.62 & 43.64 & 48.28 & 46.15 & 43.75 & 56.00 & & \\
VIII & 49.06 & 38.30 & 30.99 & 47.73 & 50.00 & 47.62 & 37.25 & \\
IX & 48.23 & 37.21 & 22.64 & 45.53 & 40.00 & 43.70 & 36.50 & 59.50 \\
\hline
\end{tabular}

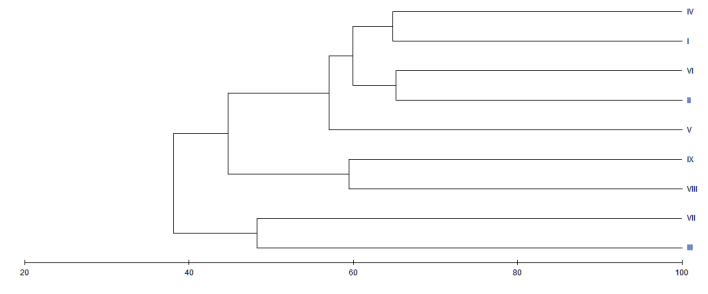

Figure 3. Cluster of similarity of oribatid genus diversity between the studied geographical regions (Legends: See the table 1).

The cluster in figure 3 shows that, from North to South of Vietnam, the oribatid genera are grouping in five main regions, as followings:

(1) The region between (I) Northwest and (IV) Red River Delta, with the similarity index of $64.81 \%$.

(2) The region between (II) Northeast and (VI) North Central, with the similarity index of $65.22 \%$.

(3) The region of (V) Red River Delta: NP Cat $\mathrm{Ba}$ Island is separated from the (1) and (2) regions, with the similarity index of around $58 \%$.

(4) The region of (VII) Central North and (III) Red River Delta: Uplands, with the similarity index of $48.28 \%$. 
(5) The region between (IX) Southern Mekong River Delta: NP Cat Tien and (VIII) Southern - Mekong River Delta: NP Bu Gia Map, with the similarity index of $59.50 \%$.

\section{Zoogeographical division of Vietnam based} on its oribatid species

The distribution and zoogeographical division of oribatid species of Vietnam are presented in the table 4 and in the figure 4.

The cluster in figure 4 shows that, the oribatid mite fauna of Vietnam is grouped in three main regions: Northern, Central and Southern. However, there are differences between these three parts of the country, and even between different sub-regions of these parts.

Table 4. Jaccard similarity index of oribatid species diversity between the studied geographical regions (Legends: See the table 1)

\begin{tabular}{ccccccccc}
\hline & I & II & III & IV & V & VI & VII & VIII \\
\hline II & 59.30 & & & & & & & \\
III & 9.40 & 8.93 & & & & & & \\
IV & 53.55 & 45.21 & 16.67 & & & & & \\
V & 46.71 & 41.54 & 12.50 & 45.61 & & & & \\
VI & 51.43 & 52.17 & 11.36 & 50.82 & 43.40 & & & \\
VII & 22.66 & 27.71 & 27.59 & 26.67 & 22.39 & 36.62 & & \\
VIII & 20.57 & 17.39 & 4.55 & 19.67 & 18.87 & 17.54 & 11.27 & \\
XI & 20.92 & 17.82 & 3.95 & 16.13 & 12.94 & 14.61 & 10.68 & 50.56 \\
\hline
\end{tabular}

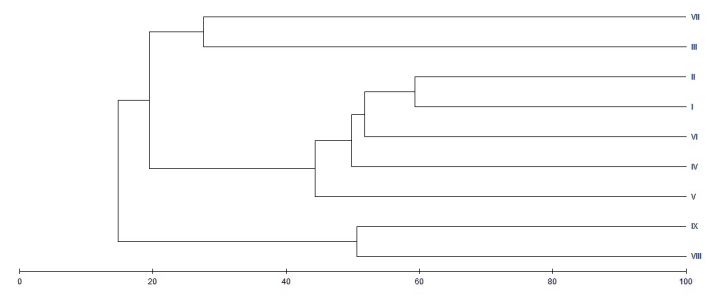

Figure 4. Cluster of similarity of oribatid species diversity between the studied geographical regions (Legends: See the table 1)

\section{DISCUSSION}

The geographical and topographical features have created a wide difference to Vietnam's landscapes: there are mountains, hills, deltas and coastal plains. In general, mountains and hills cove two thirds of the mainland. Vietnam's land is mostly hilly and densely forested, with level land covering no more than $20 \%$. Mountains account for around $40 \%$ of the country's land area, and tropical forests cover around 42\% (Vietnam Ministry of Agriculture and Rural Development 2006) [27].

The studied results on distribution and zoogeographical division of different faunas of
Vietnam, including theses of the Birds (Vo Quy, 1971) [22], the Freshwater Fishes (Mai Dinh Yen, 1973) [32], the Mammals (Dao Van Tien, 1978) [26], and the Rodents (Cao Van Sung, 1989) [25], have concluded that, in general, Vietnam can be divided into eight natural geographical regions, as it is presented above (figure 1). However, there are some differences of the study results of distributional region and zoogeographical division, in particular faunas of Vietnam, such as the Coccinellidae (Insecta, Coleoptera) (Hoang Duc Nhuan, 1987) [19], the Fresh water Crustacea (Dang Ngoc Thanh \& Ho Thanh Hai, 2001), and the Earthworm (Oligochaeta) (Thai Tran Bai, 1985) [1]. There is also other division ( $\mathrm{Vu} \&$ Taillard, 1994) [31], after which the natural geographical regions of Vietnam maybe divided into only seven regions. According to this division, there is no Red River Delta region. According to this division, the Red River Delta, actually is divided into two parts, one belongs to Northwestern, and another to Northeastern region.

Hammer \& Wallwork (1979) [9] considered that the source for the oribatid fauna of the south Pacific is probably Southeast Asia and 
that dispersal has occurred over seas, via island "stepping stones". Vietnam is a highly interesting region from a zoogeographical aspect. Although the whole country is mainly in the Oriental region, there is distinct differentiation between northern and southern parts of the country, and even between different subportions of the northern or the southern part. The northern part is closer to the south Chinese mountain range that makes it possible for some Palaearctic elements to infiltrate into this area, while the southern part of Vietnam is closer to the Pacific region.

Based on the analysis of the oribatid mite fauna, from North to South the zoogeographical division of Vietnam can be divided into three main divisions, including:

(A) The region between (I) Northwest, (II) Northeast, (IV) Red River Delta, (V) Red River Delta: NP Cat Ba Island, (VI) North Central, with the similarity indices of $41.54-59.30 \%$.

(B) The region between (III) Red River Delta: Uplands and (VII) Central North: NP Phong Nha-Ke Bang, with the similarity index of $27.59 \%$.

(C) The region between (VIII) Southern Mekong River Delta: NP Bu Gia Map, (IX) Southern - Mekong River Delta: NP Cat Tien, with the similarity index of $50.56 \%$.

The region (A) can be divided into four subregions as followings:

(A1) Subregion between (I) Northwest and (II) Northeast, with the similarity index of $59.30 \%$.

(A2) Subregion (IV) Red River Delta.

(A3) Subregion (V) Red River Delta: NP $\mathrm{Cat} \mathrm{Ba}$ Island.

\section{(A4) Subregion (VI) North Central.}

The characteristic species are those that are considered to be special to (rare or at the limits of their distribution) or are especially abundant in a particular biotope. They are generally immediately conspicuous and easily identified. According to the analysis mentioned above, it is shown that, from North to South the zoogeographical division of Vietnam, based on the oribatid mite fauna can be divided into six sub-regions, and with their characteristic species, namely:

(i) Region between (I) Northwest and (II) Northeast (North Vietnam), with eight characteristic species including (1) Papilacarus arboriseta Jeleva et Vu, 1987; (2) Nothrus baviensis Krivolutsky, 1998; (3) Nothrus montanus Krivolutsky, 1998; (4) Gibbicepheus baccanensis Jeleva et $\mathrm{Vu}, 1987$; (5) Leobodes monstruosus Jeleva et $\mathrm{Vu}, 1987$; (6) Perxylobates brevisetus Mahunka, 1988; (7) Xylobates monodactylus (Haller, 1884); and (8) Scheloribates cruciseta Jeleva et Vu, 1987.

(ii) Region of Red River Delta (IV) (North Vietnam), with four characteristic species including (1) Kokoppia dendricola (Jeleva et $\mathrm{Vu}$, 1987); (2) Perxylobates vietnamensis (Jeleva et $\mathrm{Vu}$, 1987); (3) Scheloribates praeincisus (Berlese, 1916); and Lamellobates ocularis Jeleva et Vu, 1987.

(iii) Region of NP Cat Ba Island (V) of the Red River Delta (North Vietnam), with two characteristic species including (1) Scheloribates laevigatus (C. L. Koch, 1835) and (2) Fissicepheus elegans Balogh et Mahunka, 1967.

(iv) Region of (VI) North Central: NP Ben En (North Central Vietnam), with six characteristic species including (1) Papilacarus benenensis Vu, Ermilov et Dao, 2010; (2) Setoxylobates foveolatus Balogh et Mahunka, 1967, (3) Perxylobates thanhhoaensis Ermilov, $\mathrm{Vu}$, Trinh et Dao, 2010; (4) Xylobates lophotricus (Belese, 1904); (5) Galumna tenensis Ermilov, Vu et Nguyen, 2011; and (6) Pergalumna granulatus Balogh et Mahunka, 1967.

(v) Region between (III) the Uplands of the Red River Delta, and (VII) NP Phong Nha - Ke Bang: Central North (North Vietnam and Central North Vietnam), with four characteristic species including (1) Tectocepheus cuspidentatus Knulle, 1954; (2) Austrachipteria phongnhae Ermilov et $\mathrm{Vu}, 2012$; (3) Scheloribates praeincisus (Berlese, 1916), and (4) Galumna kebangica Ermilov et $\mathrm{Vu}$, 2012. 
(vi) Region between (VIII) Southern Mekong River Delta: NP Bu Gia Map and (IX) Southern - Mekong River Delta: NP Cat Tien (South Vietnam) of Vietnam, with eight characteristic species including (1) Arthrodamaeus vietnamicus Ermilov et Anichkin, 2011; (2) Acrotocepheus (Otocepheus) vietnamicus (Ermilov et Anichkin, 2011); (3) Unguizetes cattienensis Ermilov et Anichkin, 2011; (4) Galumna levisensilla Ermilov et Anichkin, 2010; (5) Galumna pseudokhoii Ermilov et Anichkin, 2010; (6) Neogalumna seniczaki Ermilov et Anichkin, 2010; (7) Pergalumna indistincta Ermilov et Anickin, 2011; and (8) Pergalumna yurtaevi Ermilov et Anickin, 2011.

\section{CONCLUSION}

Up to December 2013, the oribatid mite (Acari: Oribatida) fauna of Vietnam is known by 320 species (including four subspecies) belonging to 163 genera, 64 families (including two subfamilies), and 30 superfamilies. The oribatid fauna of Vietnam occupies 3.09\% (320 vs. 10,342 species), $13.05 \%$ (163 vs. 1,249 genera), and $38.0 \%$ (62 vs. 163 families) of the World oribatid fauna.

Based on the oribatid mite fauna, from North to South the zoogeographical division of Vietnam can be divided into six sub-divisions, as follows: (1) Region between Northwest and Northeast (North Vietnam), (2) Region of the Red River Delta (North Vietnam), (3) Region of the Red River Delta: National Park Cat Ba Island (North Vietnam), (4) Region of North Central: National Park Ben En (North Central Vietnam), (5) Region between the Uplands of the Red River Delta and the National Park Phong Nha - Ke Bang (North Vietnam and Central North Vietnam), and (6) Region of Southern (the Mekong River Delta): National Parks of Bu Gia and Cat Tien (South Vietnam).

Acknowledgements: This research is funded by Vietnam National Foundation for Science and Technology Development (NAFOSTED) under grant number 106.14-2012.46.

\section{REFERECES}

1. Thai Tran Bai, 1985. The Earthworm Fauna
(Oligochaeta) of Vietnam. DSc. Thesis. Lomonosov University, Moscow, USSR, 285pp. (In Russian.).

2. Balogh J., Balogh P., 1992. The Oribatid Genera of the World, HNHM Press, Budapest, V. 1 and 2, 263pp. and 375pp.

3. Balogh J., Mahunka S., 1967. New oribatids (Acari, Oribatei) from Vietnam. Acta Zoologica Hungarica, 13(1-2): 39-74.

4. Dunger W., Fiedler (Hrsg.), 1997. Methoden der Bodenbiologie. Gustav Fischer, 539pp.

5. Ermilov S. G., Anichkin A. E., 2014. Taxonomy study of oribatid mites (Acari, Oribatida) of Bu Dup - Nui Ba National Park (Southern Vietnam). Zootaxa, 3834(1): 1-86.

6. Ermilov S. G., Niedbała W., Anichkin A. E., 2012. Oribatid mites of Dong Nai Biosphere Reserve (=Cat Tien National Park) of Southern Vietnam, with description of a new species of Pergalumna (Acari, Oribatida, Galumnidae). Acarina, 20(1): 2028.

7. Ermilov S. G., Vu Q. M., 2012. Two new species of oribatid mites (Acari: Oribatida) from Phong Nha - Ke Bang National Park of central Vietnam. International Journal of Acarology. 38(2): 160-167.

8. Ghilarov M. C., Krivolutsky D. A., 1975. Identification of Soil Mites Sarcoptiformes, Nauka, Moscow, 491pp. (in Russian).

9. Hammer M., Wallwork J., 1979. A Review of the World Distribution of Oribatid Mites (Acari: Cryptostigmata) in relation to Continental Drift. Det Kongelige Danske Videnskabernes Selskab. 22(4): 3-31.

10. Jeleva M., Vu Q. M., 1987. New Oribatids (Oribatei, Acari) from the Northern part of Vietnam. Acta Zoologica Bulgarica, 33: 1018.

11. Krantz G. W., Walter D. A. (Eds.), 2009. A Manual of Acarology (3rd ed.). Texas Tech. University Press.

12. Krivolutsky D. А. (Криволуцкий Д. А.), Ву Куанг Мань, Фан Тхе Вьет) 1997. 
Панцирных клещеи (Acari: Oribatei) Вьетнама. Тропическая медицина, Т. I, Тропцентр, Наука, Москва - Ханой, 152167 (In Russian).

13. Vu Quang Manh, 1980. Mites (Acarina: Mesostigmata, Oribatei) and Collembolian (Apterygota, Collembola) community structures in the soil ecosystems of Tu Liem (Hanoi, Red River Delta) and An Khe (Tay Nguyen), Central South Vietnam. MSc. Thesis. HNUE. 62pp. (In Vietnamese).

14. Vu Quang Manh (Ву Куанг Манх) 1985. Фаунистично-Екологично иследване върху орибатеите (Acari: Oribatei) в северната част на Виетнам.- Дисертация на Канд. Биолог. Науки, София, 175 стр. (in Bulgarian).

15. Vu Quang Manh, 1990. Microarthropods (Microarthropoda) in the soil community structures of Vietnam. Vietnam Journal of Biology TCSH, 12(1): 3-10 (In Vietnamese, with summary in English).

16. Vu Quang Manh, 2007. Fauna of Vietnam T. 21: Acari: Oribatida, Hanoi, Vietnamese Academy of Sciences \& ScientificTechniques Publishing House, 355pp. (In Vietnamese).

17. Vu Quang Manh, Ermilov S. G., Dao Duy Trinh, 2010. Two new species of Oribatid Mites (Acari: Oribatida) from Vietnam. Vietnam Journal of Biology TCSH, 32(3) : 12-19

18. Vu Quang Manh, 2013: The Oribatid mite (Acari: Oribatida) fauna of Vietnam. Institute of Biodiversity and Ecosystem Research (IBER: BAS), DSc. Thesis, 205pp. (www.ecolab.bas.bg/main/ Members/ gpv/ Vu.../ Vu_Manh_Thesis_all.pdf).

19. Hoang Duc Nhuan, 1987. On the boundary of the Oriental region. Vietnam Journal of Biology TCSH 9(2): 5-14 (in Vietnamese with summary English).

20. Norton R. A., Behan-Pelletier M., 2009. Chapter 15. Suborder Oribatida. In: Krantz G. W. and Water D. E. (eds.) A manual of acarology. Third edition. Texas Tech
University Press, Lubbock Texas, 430-564.

21. Primer E Ltd., PRIMER 6 for Window, 2007. Version 5.2.4. (http://www.primere.com)

22. Vo Quy, 1971. Biology of common nesting birds in Vietnam. Scientific Techniques Publishing House. Hanoi, 283pp (In Vietnamese).

23. Schatz H. et al., 2011. Suborder Oribatida van der Hammen, 1968. In: Zhang Z.-Q. (ed.). Animal biodiversity: An outline of higher-level classification and survey of taxonomic richness. Zootaxa, 3148. 141148.

24. Subias L. S., 2013. Listado sistemático, sinonímico y biogeográfico de los ácaros oribátidos (Acariformes: Oribatida) del mundo (excepto fósiles) Graellsia 60 (número extraordinario). Online version accessed in May 2013. 570p. (http://www.ucm.es/info/zoo/Artropodos/ Catalogo.pdf).

25. Cao Van Sung, 1989. On the problem of zoogeographical division of the rodent fauna of Vietnam. Vertebrata Hungarica, XXIII: 57-66.

26. Dao Van Tien, 1978. Experience of zoogeographical division of Vietnam. Zoological Journal, 57(4): 582-586 (in Russian).

27. Vietnam Ministry of Agriculture and Rural Development, 2006. Forest area and forestland not used for forestry planning. Agricultural Publishing House. Hanoi, 152pp. (In Vietnamese).

28. Vietnam National Institute for Soils and fertilizers, 2002. The basic information of main soil units of Vietnam. Thegioi Publishers, Hanoi, 158pp.

29. Vu Q. M., Nguyen T. T., 2000. Microarthropod community structures (Oribatei and Collembola) in Tam Dao National Park. Journal of Biosciences. 25(4): 379-386.

30. Vu Q. M., 2012. Oribatid soil mite (Acari: Oribatida) of northern Vietnam: Species 
distribution and densities according to soil and habitat type. The Pan-Pacific Entomologist, 87(4): 209-222.

31. Vu T. L., Taillard C., 1994. Atlas of Vietnam (Cartographic material), RECLUS,
Montpellier, Paris, 421 pp.

32. Mai Dinh Yen, 1973. On the geographical feature of fish fauna in North Vietnam. Vietnam Geolo-Biological Journal, 11, 1-2 (in Vietn. with Eng. Summary).

\title{
PHÂN VÙNG ĐİA ĐỘNG VẠTT VIÊTT NAM \\ TRÊN CƠ SỞ KHU HỆ ĐộNG VẬT VE GIÁP (ÁCARI: ORIBATIDA)
}

\author{
Vũ Quang Mạnh
}

Trường Đại học Sư phạm Hà Nội

\section{TÓM TẮT}

Ve giáp (Acari: Oribatida) được thu từ 50 điểm thuộc 27 tỉnh và thành phố, và 8 vùng địa lý tự nhiên của Việt Nam. Đến tháng 12 năm 2013, khu hệ ve giáp Việt Nam đã biết 320 loài (gồm 4 phân loài), thuộc 163 giống, 64 họ (gồm 2 phân họ) và 30 liên họ. Có 34,68\% tổng số loài ve giáp chỉ mới xác định được ở lãnh thổ Viêt Nam; 48,44\% tổng số là những loài được ghi nhận lần đầu trên lãnh thổ Viêt Nam. Khu hệ ve giáp Việt Nam chiếm 3,09\% số loài (320 so với 10.342), 13,05\% số giống (163 so với 1.249), và 38,02\% số họ (62 so với 163), so với khu hệ ve giáp thế giới.

Trên cơ sở phân tích khu hệ động vật ve giáp, từ Bắc đến Nam, Việt Nam có thể được phân thành 6 phân vùng địa động vật, đó là (1) Vùng Đông bắc và Tây Bắc (Bắc Việt Nam), (2) Vùng Đồng bằng sông Hồng (Bắc Việt Nam), (3) Vùng Đồng bằng sông Hồng: VQG đảo Cát Bà (Bắc Việt Nam), (4) Vùng Bắc Trung bộ: VQG Bến En, (5) Vùng đồi núi thuộc Đồng bằng sông Hồng và VQG Phong Nha - Kẻ Bàng (Bắc Việt Nam và Bắc Trung bộ), và (6) Vùng Đông Nam bộ (Đồng bằng sông Cửu Long): VQG Bù Gia Mập và Cát Tiên (Nam Việt Nam).

Tù khóa: Acari: Oribatida, khu hệ động vật ve giáp phân vùng địa động vật, Việt Nam.

Ngày nhận bài: 17-7-2015 